\title{
The Subacute Effects of Indocid on Stomach and Intestine in Albino Rats
}

\author{
Omorodion Nosa Terry $^{1 *}$, Iyare Goffrey Innocent ${ }^{2}$, Nwibana Barisuka Kiofi ${ }^{3}$ \\ ${ }^{\mathrm{T}}$ Department of Medical of Medical Laboratory Science, School of Basic Medical Sciences, College of Medicial Sciences \\ ${ }^{2}$ Department of Medical Laboratory Sciences, School of Basic Medical Sciences, College of Medical Sciences, \\ Igbinedion University, Edo state, Nigeria \\ ${ }^{3}$ River state College of Health Sciences and Management Technology, Portharcourt, River State, Nigeria
}

*Corresponding Author

Omorodion Nosa Terry

\section{Article History}

Received: 09.11 .2020

Accepted: 22.11.2020

Published: 25.11 .2020

\begin{abstract}
The effect of Indocid® was determined using thirty (30) albino rats of mixed sex, aged 3 months weighing 110-200g. They were acclimatized to their environment for 2 weeks during which they were fed with standard pelleted feed and water. The study is divided into acute toxicity testing and main experimental phase. The acute toxicity testing for the determination of the median lethal dose was ascertained using 12 rats divided into groups $\mathrm{K}$, L, M. The main experiment using 18 rats divided into groups A, B, C, D, E and F of three (3) rats in a group in different cages, cage A served as control. The rats were orally administered graded doses of Indocid dissolved in water once daily along with their feed for 30 days. Cages B-F received 3.0, 2.5, 2.0, 1.5 and $1.0 \mathrm{mg} / \mathrm{kg}$ respectively and were closely observed. At day 31, the rats were randomly selected, sacrificed, the stomach, and small intestine were excised, examined grossly and subsequently processed for light microscopy. Grossly the organs and tissue appeared to have several perforations especially evident in the small intestine. Further histological examination revealed erosion of the stomach and intestine. This result forms the basis for further research into the danger posed to indiscriminate users of Indocid®.
\end{abstract}

Keywords: Indocid, Subacute, Stomach.

\section{INTRODUCTION}

In Nigeria, there is an uncontrolled sale of drugs and chemicals to the populace until relatively, 2000. Even when the enabling law was made, it was hardly observed or implemented. Sometimes some of the drugs and their acclaimed effects are never scientifically investigated [1].

This worrisome lack of dependable and readily available information in regard to potentially toxic ingredients contained in most drugs and chemicals commonly used in our environment may constitute hazard [2]. In addition, indiscriminate used of these chemical compounds have resulted in rapid and unprecedented scale of environmental pollution. In the control of pests these chemical substances are commonly used as bait. The documented effects range from teratogericity [3], genotoxity [4] to death due to poisoning as was reported by Mullet et al., [5].

These pesticides are commonly sold in open markets usually unsupervised and unchecked. Most often they are hawked on the street. Sometimes the sellers apart from not even knowing what is in their possession are not qualified either by training or law to handle such substances. These sellers are mainly charlatans and their victims are usually illiterate members of the society or sometimes the ignorant literates as well. They are sold under driving and persuasive advertisement in commuter buses and local markets.

Indocid ${ }^{\circledR}$ originally was commonly used as a drug for treatment and management of certain degree of pain in humans. However, in the recent times its used has been extended to pest elimination and control. It is usually mixed with foodstuffs and kept as bait in areas usually ravaged by the pests. The most common pests involved are rats. This has

Copyright $\odot 2020$ The Author(s): This is an open-access article distributed under the terms of the Creative Commons Attribution 4.0 International License (CC BY-NC 4.0) which permits unrestricted use, distribution, and reproduction in any medium for noncommercial use provided the original author and source are credited. 
made it possible for the drug to find its way into the food chain such that might hamper their health, affect their behavior. Besides, there has been an increasing report on the dangers and havoc caused to life in Nigerian Newspapers [6].

In aquatic life, the effect of these pesticides infiltration into water is likely to affect fish and other likes in aquatic and terrestrial vertebrates including man [7]. For instance, there are some reported cases of encephalitic tremor traced to the consumption of yam tubers, contaminated with the pesticide [8]. This type of occurrences is usually seen in developing countries, which are usually characterized by poverty and ignorance. However, in Nigeria the use of the pesticides especially indocid will be limited by the prevailing custom (i.e. those that eat the pest as delicacy). Pesticide study therefore will form a good basis of environmental monitor. Hence, the research aim is to determine the Subacute Effects of Indocid on Stomach and Intestine in Albino Rats.

\section{MATERIALS AND Methods}

Thirty (30) albino rats of mixed sexes, aged 2-3 months, weighing 110-200g were used. They were obtained from Animal House of Physiology Department, University of Nigeria, Enugu Campus. The rats were kept at a temperature of $32^{\circ} \mathrm{C}$ with a 12:12 light: dark cycle. They were kept in stainless steel wire mesh cages. The animals were fed with starter's feed and water. The animals were maintained and handled in accordance with the standard guide for the care and use of laboratory animals. The animals were divided into six groups and each group had three rats (group A, B, C, D, E and F), group A served as control. The animals were fed for 30 days. Standard laboratory reagents were used for tissue processing.

\section{Acute Toxicity Testing}

The method of Litchfield and Wilcoxin [9] as described Shetty and Anika [10] was used. In this procedure, 3 groups of albino rats weighing between 110-200gm with each group containing 4 rats. The three groups (K-M) of rats were treated orally at the following dosage rats of $5.0 \mathrm{mg} / \mathrm{kg}, 10 \mathrm{mg} / \mathrm{kg}$ and $15 \mathrm{mg} \mathrm{kg}$ respectively for K-M. Clinical symptoms were not immediate and deaths were observed after 48 hours. The rats started dying at dose of $10.0 \mathrm{mg} / \mathrm{kg}$.

The only immediate effect of the drug on the rats was distressed breathing, coughing, sneezing immediately after the administration of the drug to the rats. The dead rats had abdominal bloating.

Table-1: Determination of dose-mortality relationship of indocid ${ }^{\circledR}$ (indomethacin) in albino rats

\begin{tabular}{|l|l|l|l|l|}
\hline Groups & No of Rats & Dose $(\mathbf{m g} / \mathbf{k g})$ & No. of Dead rats & \% Mortality \\
\hline K & 4 & 5.0 & 0 & 0 \\
\hline L & 4 & 10.0 & 2 & 50 \\
\hline M & 4 & 15.0 & 3 & 75 \\
\hline
\end{tabular}

The sensitivity of the rats to the lethal effect of the chemical was evenly distributed. The population sampling in an acute toxicity test allows the dose response curve to be characterized. The standard norm in practice in has been to convert the cumulative response curve to a straight line where the point estimation of the LD50 is intercept of the slope [11]. With the dose response curve in use, LD50 was determined to be $10.25 \mathrm{mg} / \mathrm{kg}$.

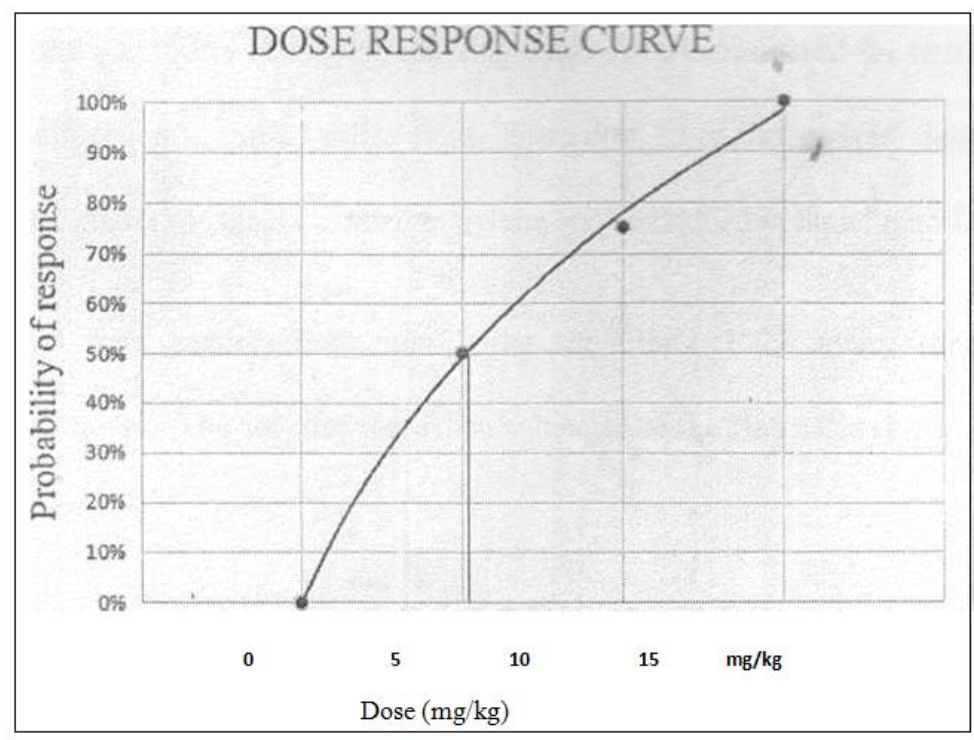


From the lethal dose determination, the dose administered during the conduct of the experiment was less than one third of the LD50 of the drug, this is expected to produce subacute effects after 30 days of administration.

\section{Design and conduct of the experiment}

The experiment is designed with six treatment group (albino rats of both sexes/groups) for the drug. Five groups were planned to allow calculation of responses to doses $(3.0,2.5,2.0,1.5,1.0) \mathrm{mg}$ indocid® $/ \mathrm{kg}$ body weight-administered orally.

A sixth group not subjected to daily treatment or handling was induced to serve as control. The rats were treated for 30 days. Each rat was observed daily and weighed every week. From the morning of days 31, 2 rats randomly selected from each cage were killed. The intestine and stomach of the sacrificed rats were dissected out, observed gross anatomically and processed histologically.

\section{Processing of samples for histology}

From each organ studied, sections were selected and processed for light microscopy. The excised organs were cleared of adhering connective tissue, fixed for twenty-four hours by immersion in formal saline fluid. Thereafter, fixed tissues were dehydrated in ascending grades of ethanol cleared in xylene and embedded in liquid paraffin wax.

The tissues were sectioned at $5 \mu \mathrm{m}$ using the Heitz 150F rotary microtome (Cambridge model). The sections were then subjected to the Haematoxylin and Eosin staining technique.

\section{Microscopy and Photography}

Microscopy and photomicrograph followed the process used by Omordion et al., [20].

\section{RESULT}

The result of this project is examined in two perspectives. These are weight changes and histological changes that is alterations of the organs of the experimental rats.

\section{Weight Changes}

During the two weeks of acclimatization following acquisition, there were no appreciable weight gain or loss observed on the rats. However, with the treatment of the rats using graded doses of Indocid® given orally, significant weight loss was observed.

\section{Histological Result}

The gastro intestinal region considered was the stomach and the intestine.

It was a simple stomach with a greatly dilated portion of the gut. It constitutes a large J-shaped sac situated in the left hypogastric region in the rat. It had 2 orifices and two surfaces. It had two borders or curvatures. The left two thirds were the fundus and body. The right one third were the pyloric antrum and pyloric canal. Attached to the lesser curvatures and the first part of the duodenum was the greater omentum (i.e. gastro colic-lineal and phrenic ligaments).

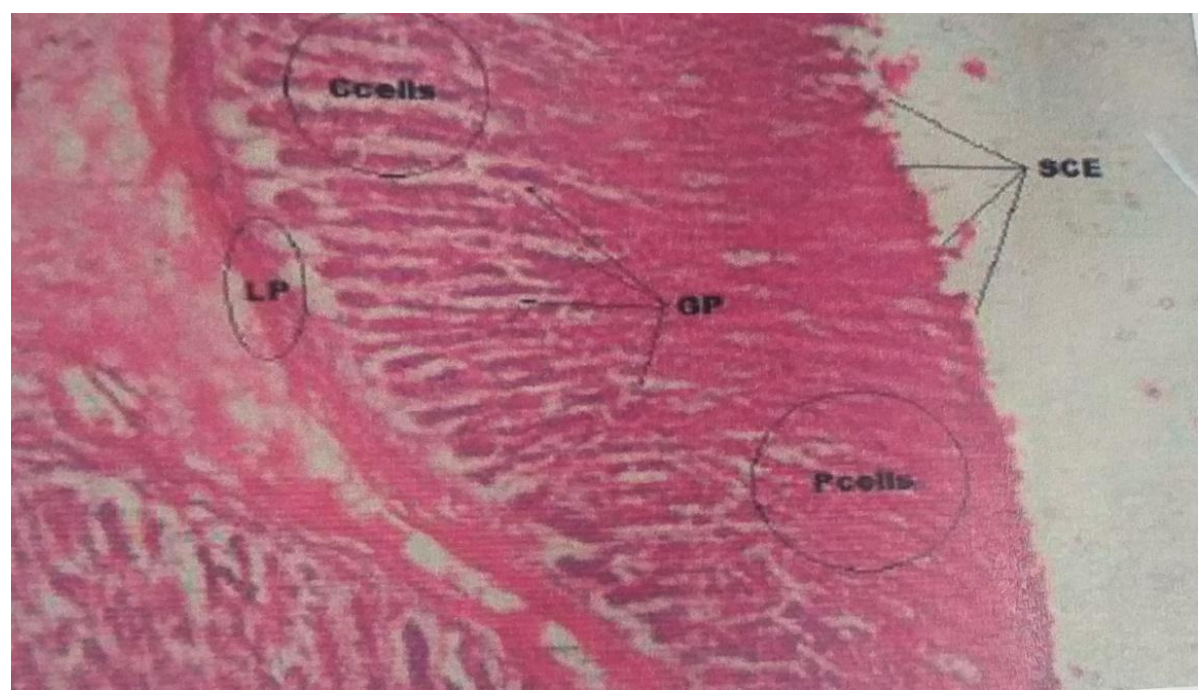

Group A Control Rat: Photomicrograph of stomach showing the parietal cells and chief cells. H\&E. X400 
Histologically, the stomach had 3 regions namely: cardiac region, fundic region, pyloric region. The wall of each region had four tunica. These are tunica mucosa, submucosa, muscularis and adventitia serosa.

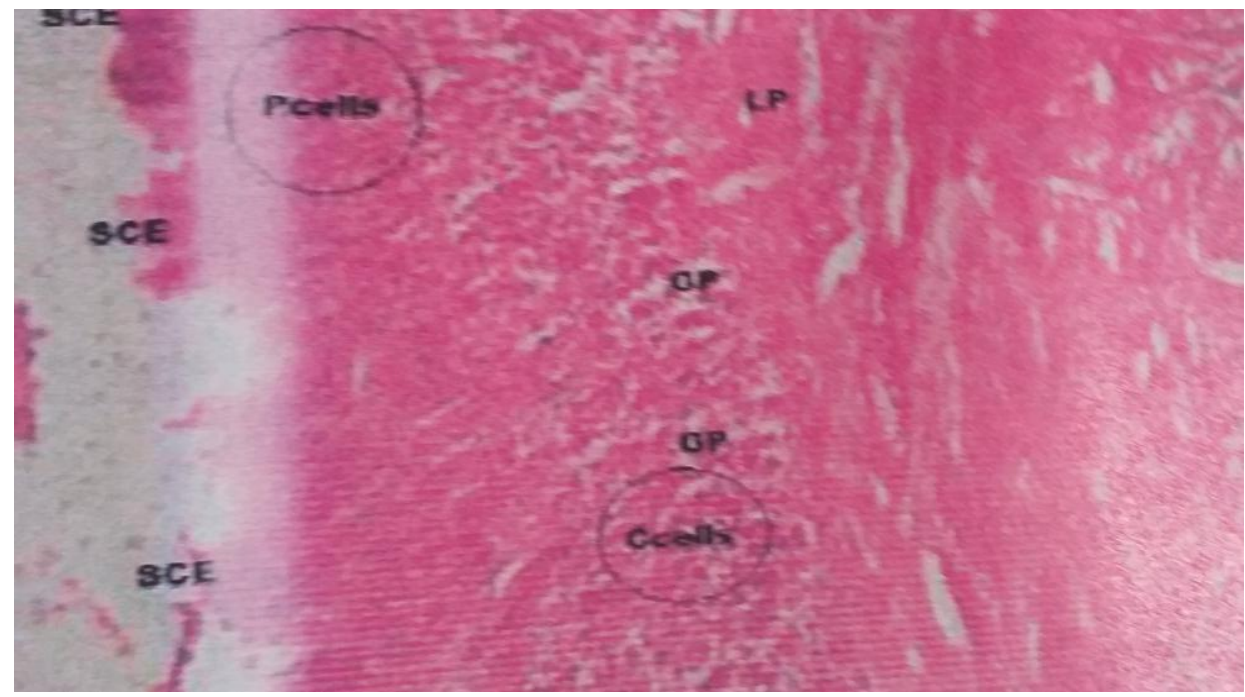

A section of the stomach tissue of a rat in group B, revealing a reduction of columnar epithelium (CE), parietal and chief cells increase (PCells and Ccells) and enormous deposition of fibrin in the lamina propria (LP). Stain: H\&E: magnification.: $\mathrm{x} 400$

This was located between the stomach and large intestine of the rats. Histologically, it has 3 similar portions: duodenum, jejenum and ileum with each portion having its peculiar features. Gross section of the intestine has four structural arrangements of intestinal wall. There is tunica mucosa, submucosa, Muscularis and serosa. Tunica mucosa was modified into villi while the submucosa contains the gland (especially bruner's gland).

Goblet cells characterize the entire lenght/surface of the intestine. There was also a presence of paneath cells at the bottom of the crypts. Isolated solitary lymphatic nodules were found in the lamina propria. Aggregation of nodules in the form of payer's patches is presented in the ileum.

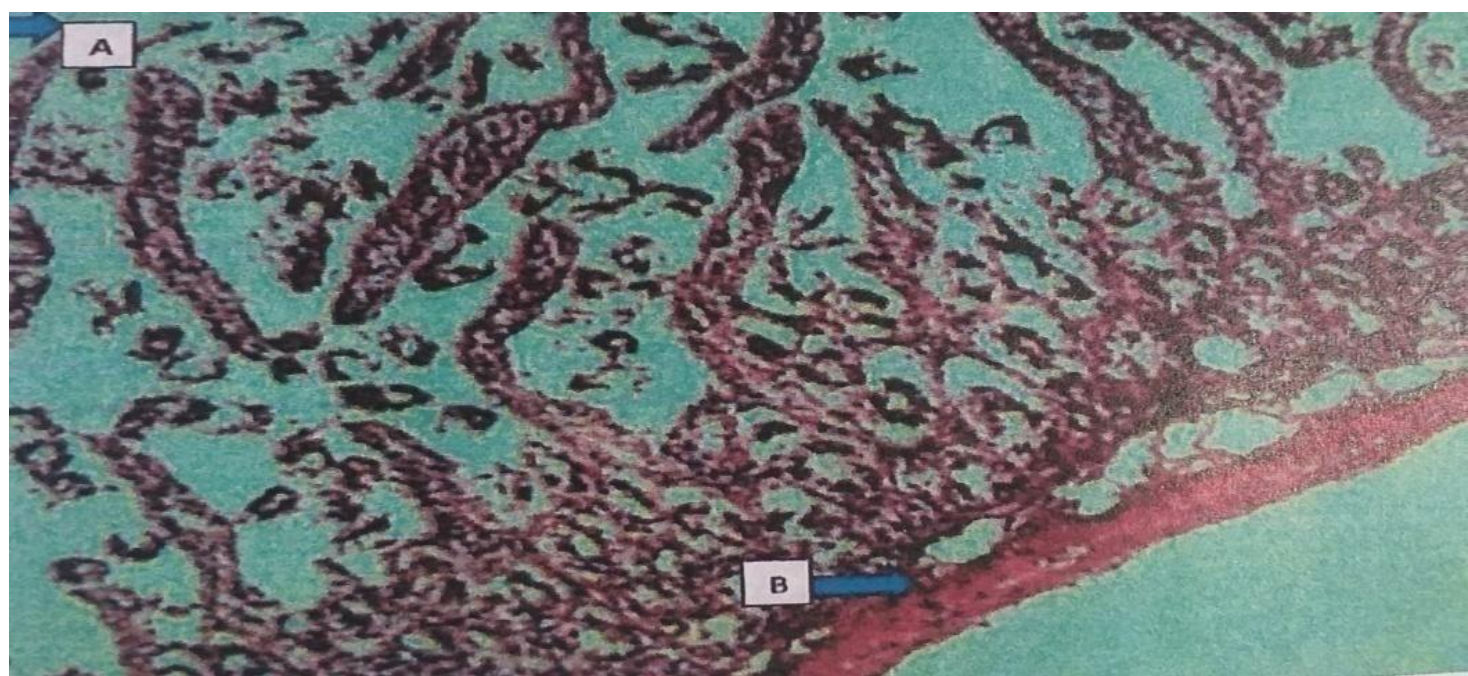

Control small intestine showing the villi (A) and brunners gland (B). H\&E. X400 MAG. 


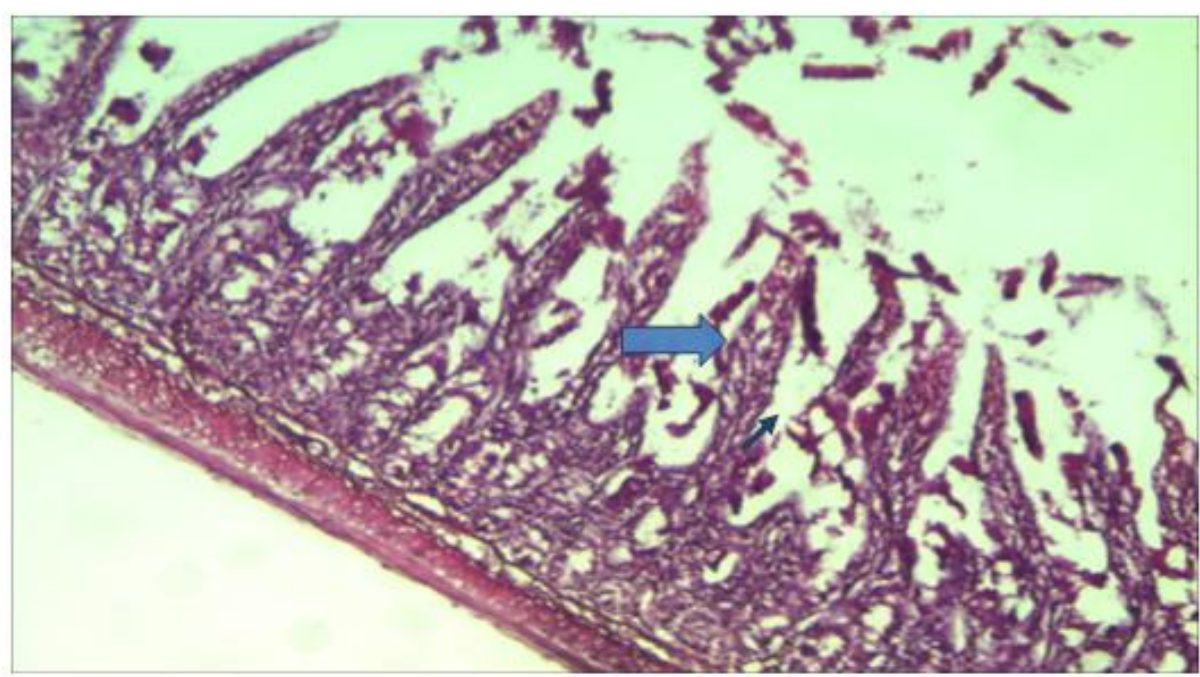

\section{$0.1-0.3 \mathrm{mg} / \mathrm{kg}$ doses cause infiltration of the lymphocytes and macrophages with an area of mucosal erosion}

\section{DISCUSSION}

The current unchecked use of Indocid ${ }^{\circledR}$ a pesticide in Nigeria either due to poverty or ignorance may constantly be a health hazard in future. The present study investigates the subacute effect of the drug in some visceral organs of albino rats. The study revealed varied histological alterations in some part of the organs.

It could be inferred that the use of Indocid for killing pests has started gaining wide acceptance because of its characteristics effects. The greatest effect of Indocid ${ }^{\circledR}$ was seen along the gastrointestinal tract where it caused local irritations leading to mucosal erosion, and varying degrees of inflammation. The added effect of bleeding could be due to inhibition of prostagladin, a platelet component which arrests bleeding. This agrees with earlier report that Indocid ${ }^{\circ}$ caused severe mucosal erosion and bleeding into the gastrointestinal tract $[12,13]$.

Fang et al., [14] also discovered that indocid can induced jejunum injury when they worked. It has also been reported that diffuse acute inflammation is seen in the villi of rats treated with indocid by Wallace et al. Suggestions was also made by some authors that the gastric ulceration by indomethacin could be due to neutrophil-dependent process [1517].

The various degrees of inflammation and necrosis triggered the severe lymphocytic infiltration of mucosa, submucosa and adventitia of small intestine revealed in this study. This effect in addition to decreased feeding led to weight loss observed in the later part of this experiment. Besides, there were numerous tubular casts observed. The necrosis resulting from Indocid consumption was in agreement with the findings of Brunel [18], and Slaggle [19], in which they explain that the necrosis could have resulted from the drug inhibiting cellular enzymes.

\section{CONCLUSION}

In the light of indiscriminate use of pesticide in farms, and our environments and its concomitant effect in pollution, and how they may find their way into the food chain of man and livestock and cause health havoc.

This experiment suggests that long term administration of indocid will cause several sub-acute effects. This can form the basis for further research into the danger posed on both rural and urban dwellers by indiscriminate use of this compound.

\section{REFERENCES}

1. Forget, G. (2010). Pesticides in third World, Topical. 44:30-33.

2. Stein, H. (2018). A large clinical manual: internal medicine, diagnosis and therapy, U.S.A. Appleton and Lange, 576.

3. Seifert, H. S. H., \& Casida, L. G. (2017). Tropical animal health, London Kluwer academic publishers. 100-105.

4. Butterowrth, B. E., Smith-Oliver, T., Earle, L., Loury, D. J., White, R. D., Doolittle, D. J., Working, P. L., Cattley, R. C., \& Jirtle, R., Michslopoulos, G. (2008). Use of Primary Cultures of Human Record. 49(5): 1075-1084.

5. Muller, G. J., Hofman B. A., \& Lamprecht, H. H. (2016). Drug and poison information - the tygerberg experience, South Africa. 83(6): 395-399. 
6. Ejekwu, W., Akintowa, A., \& Coker, H. A. B. (1995). Pesticide Exposure in Agricultural Workers in Nigeria Research. 2:107-112

7. Guenzi WD (2018): Effects of pesticides on non-target invertebrate in fresh water and soil-pesticides in soil and water, soil science society of American- incorporated publishers. Pp. 341-345.

8. Osuntokun, O. (2001). Blindness in Nigeria: The challenge of cataract blindness. The Cataract Backlog. 4th Faculty of Ophthalmology lecture. National Postgraduate Medical College of Nigeria (NPMCN), 8-9.

9. Wilcoxon, J. P., Martin, J. E., \& Provencio, P. (2000). Size distributions of gold nanoclusters studied by liquid chromatography. Langmuir, 16(25), 9912-9920.

10. Nizamlýolu, F., \& Oguz, H. (2003). Occurrence of aflatoxins in layer feed and corn samples in Konya province, Turkey. Food Additives \& Contaminants, 20(7), 654-658.

11. Gohil, V. M., Hayes, P., Matsuyama, S., Schägger, H., Schlame, M., \& Greenberg, M. L. (2004). Cardiolipin biosynthesis and mitochondrial respiratory chain function are interdependent. Journal of Biological Chemistry, 279(41), 42612-42618.

12. Plaa, G. L., \& Duncan, W. A. M. (2016). Proceedings of the first International congress on Toxicology. Toxicology as a predictive science. Lond. Academic Press, 441-458.

13. Morgan, A. E., Morgan, T. A., Ian, G., Francis, W., Bryan, H., \& Ford, M. (2015), Mims Africa - London A.E. Morgans publications Ltd. 17(6): 30.

14. Fang, W. F., Broughton, A., \& Jacobson, E. D. (1977). Indomethacin-induced intestinal inflammation. The American journal of digestive diseases, 22(9), 749-760.

15. Dhillon, A. P., Anthony, A., Sim, R., Wakefield, A. J., Sankey, E. A., Hudson, M., ... \& Pounder, R. E. (1992). Mucosal capillary thrombi in rectal biopsies. Histopathology, 21(2), 127-133.

16. Karlström, L., Hansson, G., Jodal, M., \& Lundgren, O. (1987). Influence of sodium deoxycholate on morphology, net fluid transport and motility in the small intestine of the rat. Acta physiologica scandinavica, 130(2), 273-283.

17. Lendrum, A. C. (1944). The staining of eosinophil polymorphs and enterochromaffin cells in histological sections. The Journal of Pathology and Bacteriology, 56(3), 441-441.

18. Brunel, F. (1987). Not-so-resonant, resonant absorption. Physical review letters, 59(1), 52.

19. Slagle, M. A. (2001). Featured CME Topic: Pain Management. Southern Medical Journal. 94: 771-774.

20. Omorodion, N. T., Atoigwe-Ogeyemhe, E. B., Achukwu, P. U., \& Odigie, E. B. (2019). Histopathological changes associated with exposure of some viscerals and testicular tissues to bisephenol A and di(2-ethylhexyl)phthalate Tropical Journal Pharmceutical Research. 18(6):1213-1218 